\title{
Regulerer følelser
}

\author{
Toleransevindu kan benyttes som affektregulerende tiltak for pasienter med \\ personlighetsforstyrrelse.
}

D e siste årene har det vært økt oppmerksomhet og satsing på traumeforståelse i psykiatrien, og for å spre denne kunnskapen har man opprettet regionale ressurssentre om vold, traumatisk stress og selvmordsforebygging (RVTS).

\section{Bakgrunn}

Ved Alna DPS, Gruppeseksjonen, erfarte vi at tilbudet til pasienter med traumesymptomer ikke var godt nok. Flere pasienter opplevde behandlingen som belastende. Vi har derfor utviklet et stabiliseringskurs for pasienter med traumesymptomer. Samtidig har vi satset på mentaliseringsteori inspirert av Bateman og Fonagy (1). Ullevål universitetssykehus startet med mentaliseringskurs for pasienter i 2006. Institutt for gruppeanalyse (IGA) tilbyr to års modulbasert utdanning til helsepersonell. En viktig del av dette kurset er den mentaliserende holdningen til kommunikasjon. Det vil si å være spørrende, nysgjerrig, fantaserende og utforskende i relasjoner. Begge utdanningene vektlegger psykoedukative tiltak der målet er å bedre pasientens regulering av følelser. Jeg har valgt å bruke elementer fra begge teoriene $\mathrm{i}$ arbeidet med pasienter og mener det har styrket tilbudet.

\section{Hovedbudskap}

Emosjonell regulering er en svært viktig del av det psykologiske terapifeltet, og toleransevindu fra traumeteori er et redskap som gjør dette lettere tilgjengelig for pasienter med personlighetsforstyrrelse.

\section{Nøkkelord}

Les mer og finn litteraturhenvisninger på våre nettsider. \Psykisk lidelse / Terapi / Psykisk helse

\section{Nytt redskap}

I denne artikkelen vil jeg vise hvordan psykoedukative tiltak har gitt pasientene et nytt redskap, som gir økt evne til å regulere følelser. De temaene som har vært trukket inn i samtalegruppen er mentaliseringsperspektivet og toleransevindu. Jeg gjengir sitater fra pasienter som uttaler seg om hvordan de bruker redskapet toleransevindu i sin hverdag for å regulere egne følelser. Noen av disse pasientene har gått på mentaliseringskurs. Pasientene er anonymisert og har gitt tillatelse til at sitatene blir brukt i artikkelen.

\section{Mentaliseringskurs}

De siste fem årene har jeg arrangert ni mentaliseringskurs for grupper på sju til åtte pasienter med personlighetsforstyrrelser. Kurset har bestått av åtte gruppemøter med fire hovedtemaer: mentalisering, tilknytning, følelser/ følelsesregulering samt gruppeterapi. En viktig del av kurset er den mentaliserende holdningen til kommunikasjon.

Det har vært økt oppmerksomhet om mentaliseringsbasert terapi de siste årene. Samtalegrupper har blitt mindre analytiske og mer strukturerte, nettopp med ønske om å øke evnen til å mentalisere. Selve begrepet mentalisering handler om: « ... å forstå seg selv og andre, gjennom å oppfatte og tolke egen og andres mentale tilstand - utvikles i barndommen gjennom trygg tilknytning til omsorgsgiver, en eller flere» (1, s. 234). Mentalisering foregår ubevisst og bevisst i kommunikasjon mellom mennesker og er avgjørende for hvordan vi fortolker hverandre. Vi er ofte raske til å tolke hva andre mener, noe som kan føre til misforståelser. Dette kan igjen føre til konflikt og bringe oss i emosjonell ubalanse (2). Mentalisering er også å se seg selv utenfra. Et av målene med mentaliseringsbasert terapi er at følelsene ikke skal bli for sterke, da terapien fungerer best når følelsene er godt regulert. De fleste har opplevd at evnen til å mentalisere svikter. Det kan skje når vi blir stresset på grunn av prestasjonskrav, tidspress og konflikter i nære relasjoner med partner, familie, venner og liknende. Da kan vi fort si ting vi angrer på som kan skade relasjonen. Angst gir også redusert evne til å mentalisere.

\section{Stabiliseringskurs}

Stabiliseringskurs er et tilbud til pasienter med posttraumatisk stresslidelse (PTSD). PTSD kan oppstå etter traumatiske hendelser. Det kan være livstruende hendelser som krigsopplevelser, voldtekt, naturkatastrofer og enkelthendelser i relasjoner. Kompleks PTSD kan oppstå ved langvarig omsorgssvikt og overgrep i relasjo-

\section{«Terapien fungerer best når følelsene er godt regulert.»»}

ner. PTSD kan også føre til dissosiasjon, som betyr at pasienten fortrenger deler av jeget for å slippe å være i sin egen kropp. Når dette skjer, kan pasienten reagere med å bli fjern og vanskelig å få kontakt med, noe som kan være et vanlig symptom på psykose. Målet med kurset er å forstå egne symptomer og reaksjoner som anstrengelser for å unngå alt som kan minne om hendelsen. Når pasienter lærer å forstå symptomene sine, kan de trene på øvelser som har en stabiliserende effekt. Dette er i stor grad knyttet til regulering av følelser. Målet er å knytte pasienten til «her og nå» ved hjelp av sansene. For eksempel ved å rette oppmerksomheten 


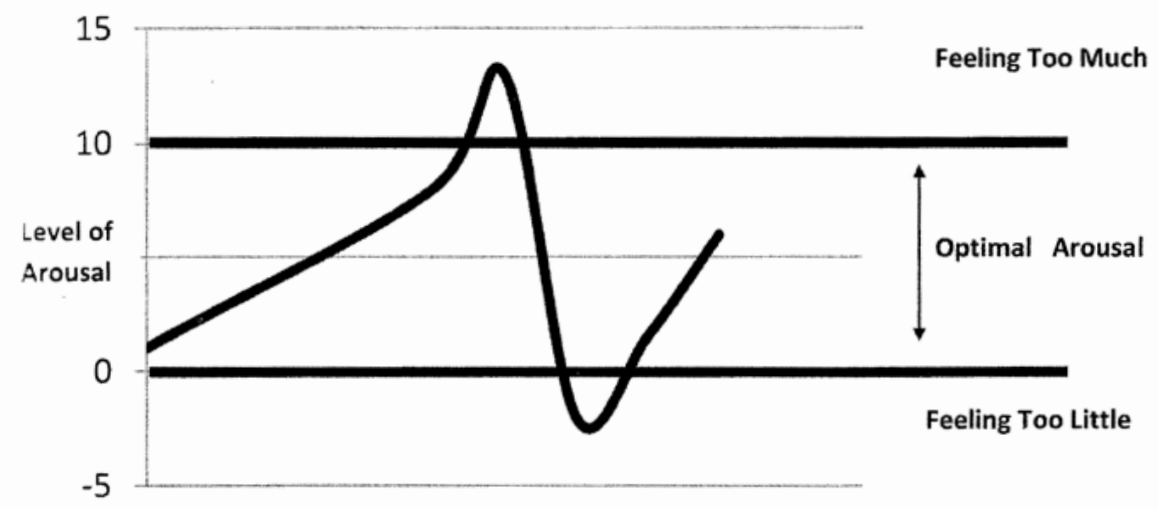

Figure 18.1. Window of Tolerance. Adapted from Ogden et al., 2006; Siegel, 1999; and Van der Hart et al., 2006.

\section{Gruppen}

De pasientene som uttaler seg her har vært med i gruppen i cirka to år. Gruppen møtes en gang per uke i halvannen time. Da jeg begynte ved Lovisenberg DPS kom jeg inn i en samtalegruppe med psykodynamisk tilnærming. Sammen med min ko-terapeut ble vi enige om å trekke inn den mentaliserende holdningen og begrepet toleransevindu. I gruppen underviste vi om toleransevindu i cirka fem til ti minutter. Dette har vært gjentatt fem-seks ganger i løpet av halvannet år, og terapeutene har også ved flere anledninger bedt pasientene reflektere over hvor de befinner seg i toleransevinduet, når de har beskrevet vanskelige relasjonelle situasjoner. Resultatet av å undervise om toleransevindu ble tydelig etter halvannet år i gruppen, da fire pasienter i løpet av 30 minutter snakket uoppfordret om utbyttet de har hatt av begrepet toleransevindu. Jeg har derfor valgt å gjengi deler av denne samtalen. Dette har vært mulig fordi jeg gjør opptak av gruppemøtene.

\section{Erfaringer}

Pasient 1: «Det (toleransevinduet) er også et veldig bra verktøy som gjør ting oversiktlig og tydelig. Jeg bruker det skjemabildet i hodet mitt noen ganger i situasjoner når jeg merker jeg er litt i ... at jeg begynner å plukke detaljer som det skal handle om, og alt mulig annet som jeg kan distrahere meg med. Hvis jeg tenker: Ok, hvor er jeg mentalt, hvor er jeg følelsesmessig? Så blir det fort ganske tydelig».

Pasient 2: «Det er merkelig hvor effektivt toleransevindu er, for jeg mener det samme.
Jeg begynner også å lete, for hva er egentlig problemet nå? Det har jeg alltid pleid å gjøre ... Hvorfor føler jeg som jeg gjør nå? Da sier jeg: Det er egentlig fordi jeg er utenfor toleransevinduet. Altså, det ligger en grunn bak der, men det behøver ikke være noe galt med meg».

Pasient 1: «Det som er så bra med toleransevindu er at da vet du hvor du er. Man kan se det og istedenfor å handle da ... det er ikke lurt å handle da ... det er ikke lurt å ta en avgiørelse, og det ville man ikke gjort ellers. Man har liksom et religiøst forhold til sine følelser og tenker at det er virkeligheten, sånn er det. Men så er det ikke sånn» ... «Jeg synes jeg får veldig mye tilbakemelding på at toleransevindu er et bra verktøy. Det funker, det er anvendelig, det blir ikke bare teori, og det er ganske tydelig i situasjoner hvis du klarer å bruke det».

\section{Avslutning}

Toleransevindu er et redskap for å se seg selv utenfra. I det øyeblikket pasienten kjenner på sterke følelser, kan han eller hun spørre seg selv: «Hvor er jeg i toleransevinduet nå?». Hvis pasienten da kan erkjenne: «Jeg er utenfor», kan det fungere som en følelsesmessig bevisstgjøring og et steg mot å se seg selv utenfra. Det neste steget i denne fasen blir å spørre seg selv: «Hva kan jeg gjøre for å komme innenfor toleransevinduet?». Når dette skjer, er det første steget mot å mentalisere for ikke å gå videre i en destruktiv kommunikasjon. Pasienten har da laget seg strategier for å håndtere tilstander som stress eller angst knyttet til konflikt i nære relasjoner. Han eller hun befinner seg da «utenfor toleransevinduet». Tiltak knyttet til denne tilstanden er det nyttig å planlegge og det kan være: be om «time out», ta en pause, gå en tur på toalettet, gå en tur eller fem rundt kvartalet. Her er vi forskjellige. Noen kan trenge en pause på noen minutter, mens andre trenger dager eller uker. En strategi er å bli enig om at vi er uenige og la diskusjonen avsluttes med det. Pasienter med unnvikende personlighetsforstyrrelse kan ha vanskelig for å si nei hvis leder spør om pasienten kan jobbe overtid. Mange svarer ja på refleks fordi de ikke har erfaring med noe annet. Pasienten blir så overveldet og befinner seg utenfor toleransevinduet. Hvis vedkommende har en strategi om å svare «det må jeg tenke på», blir det mulig for ham eller henne å komme innenfor toleransevinduet for å tenke og føle klart om en valgsituasjon.

Jeg har prøvd å vise hvorfor toleransevinduet kan brukes som redskap i mange situasjoner hvor vi som mennesker blir overveldet av følelser og trenger et redskap for å komme tilbake i modus hvor vi tenker klart. I løpet av fem år med mentaliseringkurs og gruppeterapi har jeg erfart at toleransevinduet er et redskap pasientene i denne gruppen har god nytte av. Hvorfor dette symbolet gjør det enklere å se seg selv utenfor tror jeg handler om at det er et bilde eller skjema som lett fester seg og hvor en kan plassere seg selv inn i dette bildet. Tilbakemeldingene fra pasientgruppen har vært entydig positive. IIII

Mentaliseringskursene ble holdt sammen med spesial-ergoterapeut Loes Cats, psykiatrisk sykepleier/ gruppeanalytiker Brita Stølan og psykiatrisk sykepleier Camilla Myklestad Karam som jeg takker for inspirerende og godt samarbeid. Takker også kollegaer ved Alna/Grorud DPS og Lovisenberg DPS for godt faglig miljø. En scerlig takk til psykologspesialist Irene Michalopoulos for faglige innspill til artikkel og for å holde traumefokuset oppe.

\section{REFERANSER}

Bateman AW, Fonegy, P. Mentaliseringsbasert terapi av borderline personlighetsforstyrrelse. Oslo: Arneberg forlag, 2007.

Karterud S. Gruppeanalyse og psykodynamisk gruppepsykologi. Oslo: Pax forlag, 1999.

3. 1. Anstorp T, Benum K, Jakobsen M. Dissosiasjon og relasjonstraumer, Integrering av det splittede jeg. Oslo: Universitetsforlaget, 2006.

4. Boon S, Steele K, Van der Hart O. Coping with Trauma-related dissociation. Skills training for patients and therapist. First Edition New York: W.W. Norton \& Company, 2011.

Fagartikler kan sendes til torhild.apall@sykepleien.no 